MaPan : Jurnal Matematika dan Pembelajaran

p-ISSN: 2354-6883 ; e-ISSN: 2581-172X

Volume 9, No 2, Dec 2021 (320-334)

DOI: https://doi.org/10.24252/mapan.2021v9n2a9

\title{
DEVELOPMENT OF HOTS-BASED FUNCTION DERIVATIVE WORKSHEET THROUGH A NETWORK LEARNING SYSTEM SPADA
}

\author{
Sri Satriani1), Wahyuddin'2), Andi Aliem Syahri') \\ 1,2,3 Department of Mathematics Education, Universitas Muhammadiyah Makassar \\ 1,2,3Jl. Sultan Alauddin No. 259 Makassar, Indonesia \\ Email: srisatriani@unismuh.ac.id1),Wahyu.umm@gmail.com²), \\ andialims@unismuh.ac.id ${ }^{3)}$
}

Received November 09, 2021; Revised December 23, 2021; Accepted December 30, 2021

\begin{abstract}
:
This study aims to develop a valid, effective, and practical HOTS-based worksheet for calculus courses in the Mathematics Education Department. The development of the worksheet is expected to improve critical and creative thinking skills, which is implemented through the Online Learning System (SPADA). This research is development research with the research subject being 27 students of Mathematics Education, Muhammadiyah University of Makassar. The instruments used in this study were instrument validation sheets, test, and student response questionnaires. This worksheet development process is adapted from the model of development of the 4-D models, which consists of define, design, develop, and disseminate. The results of the validation assessment were an average score of 3.61 in the valid categories. The result of the lecturers' practicality at 3.6 with the practical category. Furthermore, the results of the effectiveness assessment through the HOTS test showed that the percentage of classical completeness was $86.7 \%$. The students' responses showed a positive response to this worksheet. The assessment results showed that the average pretest was 46.85 , while the postest was 74.81 . There is an increase in the average value of higher-order thinking skills from pretest to postest in field trials. So it produces worksheets based on HOTS through SPADA that have met the valid, practical, and effective aspects and can facilitate students in practicing their higher-order thinking skills.
\end{abstract}

Keywords: Development, SPADA, Worksheet HOTS

\section{PENGEMBANGAN WORKSHEET TURUNAN FUNGSI BERBASIS HOTS MELALUI SISTEM PEMBELAJARAN DALAM JARINGAN SPADA}

\begin{abstract}
Abstrak:
Penelitian ini bertujuan untuk mengembangkan worksheet berbasis HOTS mata kuliah kalkulus di Prodi Pendidikan Matematika yang valid, efektif dan praktis. Pengembangan worksheet ini diharapkan dapat meningkatkan kemampuan berpikir kritis dan kreatif, yang diimplementasikan melalui Sistem Pembelajaran Dalam Jaringan (SPADA). Penelitian ini merupakan penelitian pengembangan dengan sampel penelitian adalah mahasiswa Pendidikan Matematika Universitas Muhammadiyah Makassar yang berjumlah 27 orang. Instrumen yang digunakan
\end{abstract}


dalam penelitian ini berupa lembar validasi instrumen, dan angket respon mahasiswa. Proses pengembangan worksheet ini diadaptasi dari model pengembangan 4-D Models yang terdiri dari pendefinisian (define), perancangan (design), pengembangan (develop), dan penyebaran (disseminate). Berdasarkan hasil penilaian validasi diperoleh skor rata-rata, yaitu aspek materi sebesar 3.61 dengan kategori valid. Hasil penilaian kepraktisan siswa diperoleh skor rata-rata sebesar 4.15 dengan kategori praktis dan kepraktisan dosen sebesar 3,6 dengan kategori praktis. Selanjutnya, hasil penilaian keefektifan melalui tes HOTS menunjukkan persentase ketuntasan secara klasikal sebesar $86.7 \%$ dan respon siswa menunjukkan respon positif terhadap worksheet ini. Hasil penilaian tes menunjukkan rata-rata pretest diperoleh 46,85, sedangkan postest diperoleh 74.81. Artinya, terdapat peningkatan rata-rata nilai kemampuan berpikir tingkat tinggi dari pretest ke postest dalam ujicoba lapangan, sehingga worksheet berbasis HOTS melalui SPADA telah memenuhi aspek valid, praktis, dan efektif serta dapat memfasilitasi siswa dalam melatih kemampuan berpikir tingkat tinggi.

Kata Kunci: Pengembangan, SPADA, Worksheet HOTS

How to Cite: Satriani, S., Wahyuddin, \& Syahri, A. A. (2021). Development of Hots-Based Function Derivative Worksheet Through A Network Learning System SPADA. MaPan : Jurnal Matematika dan Pembelajaran, 9(2), 320-334. https:/ / doi.org/10.24252/mapan.2021v9n2a9.

\section{INTRODUCTION}

7 he industrial revolution 4.0 is one of the manifestations of modern German technology projections, which are applied by improving manufacturing technology, creating a policy framework, etc. Especially in the field of Industrial Revolution 4.0 learning, it is used to support thinking patterns aimed at increasing the innovative creativity of students so that they can print the next generation that can compete (Alam, 2019). Students must possess at least four abilities, including critical thinking skills, creative thinking skills, communication skills, and collaboration skills. Education manifests a dynamic and progressive culture (Ikman, Hasnawati, \& Rezky 2016). One of the most important branches of education is mathematics. Mathematics is one of the basic sciences that has an essential role in mastering science and technology. Therefore, mathematical knowledge is a facility to foster critical, logical, systematic, and creative thinking steps (Khoriyah \& Oktiningrum, 2021). Students' success in understanding a concept is obtained when they have optimized higher-order thinking. 
Students are not only required to remember and be aware of a concept, but they can also analyze, synthesize, and evaluate a concept well (Khoriyah \& Oktiningrum, 2021). Concepts that are understood with these activities are expected to be embedded in students' memories to store long-term memory. Therefore, students need higher thinking skills, especially those who want to be involved in mathematics as educators who will undoubtedly face students who will become the successors of the nation's hopes. Therefore, prospective educators should also have HOTS abilities from an early age, which can later be transferred to students during the learning process. The above statement is in line with the goal of national education, which is to create creative human beings. Therefore, students must have high-level thinking skills (Alam, 2019). Yee, Widad, Jailani, Tee, Razali, and Mohaffyza (2011) also show that HOTS skills are essential for learning systems, thinking skills, and learning effectiveness.

Higher order thinking skills are processes that not only memorize, remember and convey information that is known to be conveyed again but also optimize its ability to solve challenges or problems (Pratama \& Istiyono, 2015; Saregar, Latifah, \& Sari, 2016). In the revision of the HOTS bloom taxonomy, the realm of C4-C6 is to analyze, evaluate and create (Karsono, 2017).

In fact, students of the Mathematics Education Department, who are also prospective educators, tend only to want to solve problems considered easy and give up on more challenging math problem-solving issues. If students have been faced with non-routine questions that involve reasoning, they are tough to solve. These problems, especially in advanced calculus courses. Previous research conducted (Nurwahidah, 2018) also found that students were not used to solving problems involving reasoning, so they could not solve complex physics problems. Likewise, the research result (Kurniawati, 2014) found that students' HOTS abilities in the cognitive realm C4-C6 were less than $50 \%$. Therefore, it is necessary to develop worksheets with HOTSbased that students can use to practice their higher-order thinking skills to develop their critical, logical, and creative thinking skills on the problems given.

One of the learning strategies that educators can use to improve learning activities is making worksheets (Rahmatillah, Halim, \& Hasan, 2017). Giving worksheets is one of the efforts to help students be more enthusiastic and active in constructing their knowledge (Anggraini, Anwar, \& Madang, 
2016). This statement is in line with Mairing (Prastiti, Tresnaningsih, \& Thaib, 2019), which states that student worksheets can help students increase their knowledge and motivation to learn. Therefore, researchers are keen to develop worksheets for learning mathematics with calculus-based courses on HOTS to produce a prototype worksheet for calculus courses that the student uses to improve high-level thinking skills for learning more meaningful. By developing this student worksheet, students can optimize their critical thinking skills (Prasadi, Wiyanto, \& Suharini, 2020). Several previous studies have examined the development of worksheets, including (Pamungkas, Kurniasi, \& Anton, 2020); (Widyawati \& Sujatmika, 2020); (Arnellis, Suherman, \& Amalita, 2019); (Prasadi, Wiyanto, \& Suharini, 2020); and (Anggraini, Anwar, \& Madang, 2016). However, from some of these studies, on average, they are still developing worksheets HOTS-based in different subjects. Still, no one has developed worksheets student-level based on HOTS for Calculus courses at the high school level.

\section{METHODS}

The type of research is an R\&D (Research and Development) research. This research was held on June-August 2021 at the University of Muhammadiyah Makassar. The population of this study was students of the class of 2020 Mathematics Education Department, the University of Muhammadiyah Makassar used the saturated sample technique that the populate also acted as the research sample. The number of samples in this study amounted to 27 people. The procedure used in this study uses 4-D who consists of four stages called define, design, develop, and disseminate. The define stage aims to define the terms in learning. The design stage aims to prepare a prototype learning device. This stage consists of three steps: (1) preparation of tests, (2) selection of appropriate media, and (3) selection of formats that include needs map, worksheet outline, and worksheet design. The development stage aims to produce a worksheet that has been revised by the validator/expert. This stage includes (1) validation by experts followed by revision, (2) simulation, namely activities to operate the teaching plan, and (3) limited trial with real students. The results of stages (2) and (3) can be used as the basis for revision. The next step is further testing on students through the SPADA service of the Muhammadiyah University of Makassar. The dissemination stage is the stage of using worksheets that have been developed on a bigger scale, for example, in other courses or subjects outside the 
Mathematics Education study program.

Collection techniques used are (1) Interview, activities carried out by discussing with colleagues and several students related to the learning process, learning resources used, as well as student difficulties in function derivative materials. (2) Questionnaire, consists of an expert validation questionnaire, a practicality questionnaire, and a student response questionnaire. (3) Test, given are HOTS questions on function derivative material. The test instrument was used to see the effectiveness of the worksheet. The research instruments used include (1) interview guidelines, (2) worksheet validation sheets, consisting of material validation sheets, and language validation sheets, (3) practicality worksheets, consisting of practicality questionnaires given to teachers and students, and (4) worksheet effectiveness sheets consisting of the HOTS test sheet and student responses.

Analysis techniques carried out consisted of worksheet validation sheet analysis. Analysis of student practicality questionnaires and analysis of the effectiveness of the worksheet in terms of HOTS test results obtained through pretest and posttest and student responses to field trials. Worksheet validation was measured using a five-scale Likert scale, starting from a score of 1 (not appropriate) to a score of 5 (very appropriate). The average score obtained from the validator's assessment, with the formula.

$$
\underline{V}=\frac{\sum_{i=1}^{n} R A_{i}}{n}
$$

$\underline{V}$ is the average validity score, $R A_{i}$ is the average score of the validation of the $\mathrm{i}$-th aspect, and $\mathrm{n}$ is the number of aspects. Furthermore, for the validity criteria of the worksheet in table 1 below.

Table 1. Criteria for Worksheet

\begin{tabular}{ccc}
\hline No. & Interval Validity & Criteria for Validity \\
\hline 1 & $\underline{V}>4.2$ & Very valid \\
2 & $3.4<\underline{V} \leq 4.2$ & Valid \\
3 & $2.6<\underline{V} \leq 3,4$ & Fairly valid \\
4 & $1.79<\underline{V} \leq 2.6$ & Less valid \\
5 & $\underline{V} \leq 1.79$ & Invalid \\
\hline
\end{tabular}

Furthermore, the LKPD revision worksheet is carried out according to the suggestions from the validator so that a valid LKPD is obtained. Practicality data was obtained from the results of practicality questionnaires for lecturers and students. The practicality questionnaire was measured using 
a Likert scale starting from a score of 1 (not appropriate) to 5 (very appropriate). The questionnaire consists of 20 statements with 17 positive statements and 3 negative statements. The average practicality score of teachers and students is calculated using the formula.

$$
\underline{P}=\frac{\sum_{i=1}^{n} R A_{i}}{n}
$$

$\underline{P}$ is the average practicality score, $R A_{i}$ is the average score of the validation of the I aspect, $\mathrm{n}$ is the number of aspects. Next, match the practicality average $(\underline{P})$ with the LKPD practicality criteria in table 2 below.

Table 2. Criteria Worksheet Practicality

\begin{tabular}{ccc|}
\hline No & Interval Practicality & Criteria \\
\hline 1 & $\underline{P}>4.2$ & Very practical \\
2 & $3,4<\underline{P} \leq 4.2$ & Practical \\
3 & $2,6<\underline{P} \leq 3,4$ & Quite Practical \\
4 & $1,79<\underline{P} \leq 2,6$ & Less Practical \\
5 & $\underline{P} \leq 1,79$ & Not Practical \\
\hline
\end{tabular}

Data were obtained from student tests which included pretest and posttest of students' higher-order thinking skills and student responses. The test consists of 3 essay questions, each containing a HOTS indicator. The average yield HOTS student test calculated using the formula

$$
\underline{H}=\frac{\text { score obtained }}{\text { the maximum score }} \times 100
$$

With $\underline{H}$ is the average value of the results of HOTS students. Next, match the average value $(\underline{H})$ with the HOTS level criteria in table 3 below:

Table 3. HOTS Level Criteria

\begin{tabular}{ccc}
\hline No & Interval Value & Criteria \\
\hline 1 & $\underline{H}>80$ & Very high \\
2 & $70<\underline{H} \leq 80$ & High \\
3 & $60<\underline{H} \leq 70$ & Enough \\
4 & $50<\underline{H} \leq 60$ & Low \\
5 & $\underline{H} \leq 50$ & Very low \\
\hline
\end{tabular}

The average score of student questionnaire responses was calculated using the formula.

$$
\underline{R}=\frac{\sum_{i=1}^{n} R_{i}}{n}
$$


$\underline{R}$ is the average value of student response, $R_{i}$ is the average value of student response to- $i$, and $n$ is a lot of students. Furthermore, matching the average response $(\underline{R})$ with student response criteria in table 4 below:

Table 4. Criteria for Student Response

\begin{tabular}{ccc}
\hline No. & Interval Response & Criteria \\
\hline 1 & $\underline{R}>4.2$ & Very Good \\
2 & $3.4<\underline{R} \leq 4,2$ & Good \\
3 & $2.6<\underline{R} \leq 3.4$ & Enough \\
4 & $1.79<\underline{R} \leq 2.6$ & Low \\
5 & $\underline{R} \geq 1.79$ & Very low \\
\hline
\end{tabular}

\section{RESULTS AND DISCUSSION}

Worksheet Development Process

\section{Define Stage}

a. Initial and final analysis

This part was conducting interviews with peer lecturers in charge of the course calculus and several students in the 2020 Mathematics Education Study Program. The initial-final analysis was carried out in three steps, namely observing the learning process, interviews with lecturers and students, and observing the learning tools used. Based on the results of observations and interviews with peer lecturers who are influential in calculus courses in the learning process, it is known that learning has not tried to use HOTS in the learning process but still emphasizes lecturercentered learning.

In solving calculus course questions, especially function derivatives, the emphasis is on memorizing formulas rather than building student understanding of concepts. Students are easily mistaken in answering questions related to the application of function derivatives. Students are still accustomed to routine questions and have a manageable difficulty level. Students have not been instructed to solve function derivative problems because they are still focused on existing formulas. Students' conceptual understanding of the application material for function derivatives is still less than $50 \%$, meaning that students still lack a good understanding of the circumference and area of a circle. To develop HOTS in learning, especially on the derivative concept material itself, in class, students are not only can remember formulas, understand, and apply them, but students must also analyze given mathematical problems, 
evaluate the results of their work, and create new ways or points of view or create their knowledge to solve problems (Dosinaeng, Leton, \& Lakapu, 2019). Therefore, it is necessary to develop a HOTS-based worksheet that contains problems of daily life and work steps. It requires students always to be active and independently solve them. The worksheet's work steps will lead students to find the concept of function derivative material. According to Wulandari and Susanti (2019), the student activity sheets choose because they can present the course material to be delivered and accompanied by HOTS-based practice questions and many evaluations. The questions developed will refer to HOTS-based questions.

b. Task Analysis

This stage is the main task that students must master to achieve the specified competencies where teachers can familiarize students with carrying out the teaching and learning process using HOTS, which aims to hone their thinking and reasoning skills where indicators that students must master include analyzing (C3), evaluates (C4) and creates (C6) which is adapted to the CPL and CPMK derived function materials. The following items are presented on the worksheet developed through task analysis, namely 1) The contents of the tasks given in the derivative function materials based on HOTS nuanced learning, and 2) The contents of the tasks contain daily life problems that train reasoning and HOTS indicator.

c. Concept Analysis

This stage analyzes the concept of derived function material developed systematically, namely applying function derivative material in everyday life. The learning concept developed can also be equated with the initial and final analysis, student analysis, task analysis, and HOTS nuanced learning and skill standards achieved. According to Widana (2018), Grades HOTS indirectly contribute to positive learning to improve understanding of the mathematical concepts.

\section{Design Stage}

Stages of the design carried out as follows.

a. Preparation Test

Preparation of test questions HOTS given to see students' initial ability to the material loop and final abilities after using HOTS-based worksheets. The test questions consist of 3 essay questions containing 3 HOTS indicators. 
b. Selection of Format

1) Developing Requirements Map

The results of the needs map Worksheet preparation provide information about the number of worksheets that should be created.

2) Arrange the Outline of the Worksheet.

The developed in this study is the worksheet for students what consists of three parts: the initial section containing the front cover page, identity page worksheet, introduction, table of contents, instructions for using the worksheet, base competencies, learning objectives, keywords, concept maps, and history. The content section contains material orientation, activity sheets, supporting information, conclusions, asking questions, exercises, summarizing, and competency tests. The last section contains a bibliography and a back cover page.

3) The Initial Design of the Worksheet

The initial worksheet design was arranged according to the media selection and the preparation format of the worksheet. The HOTS-based worksheet design can be seen in figure 1 .

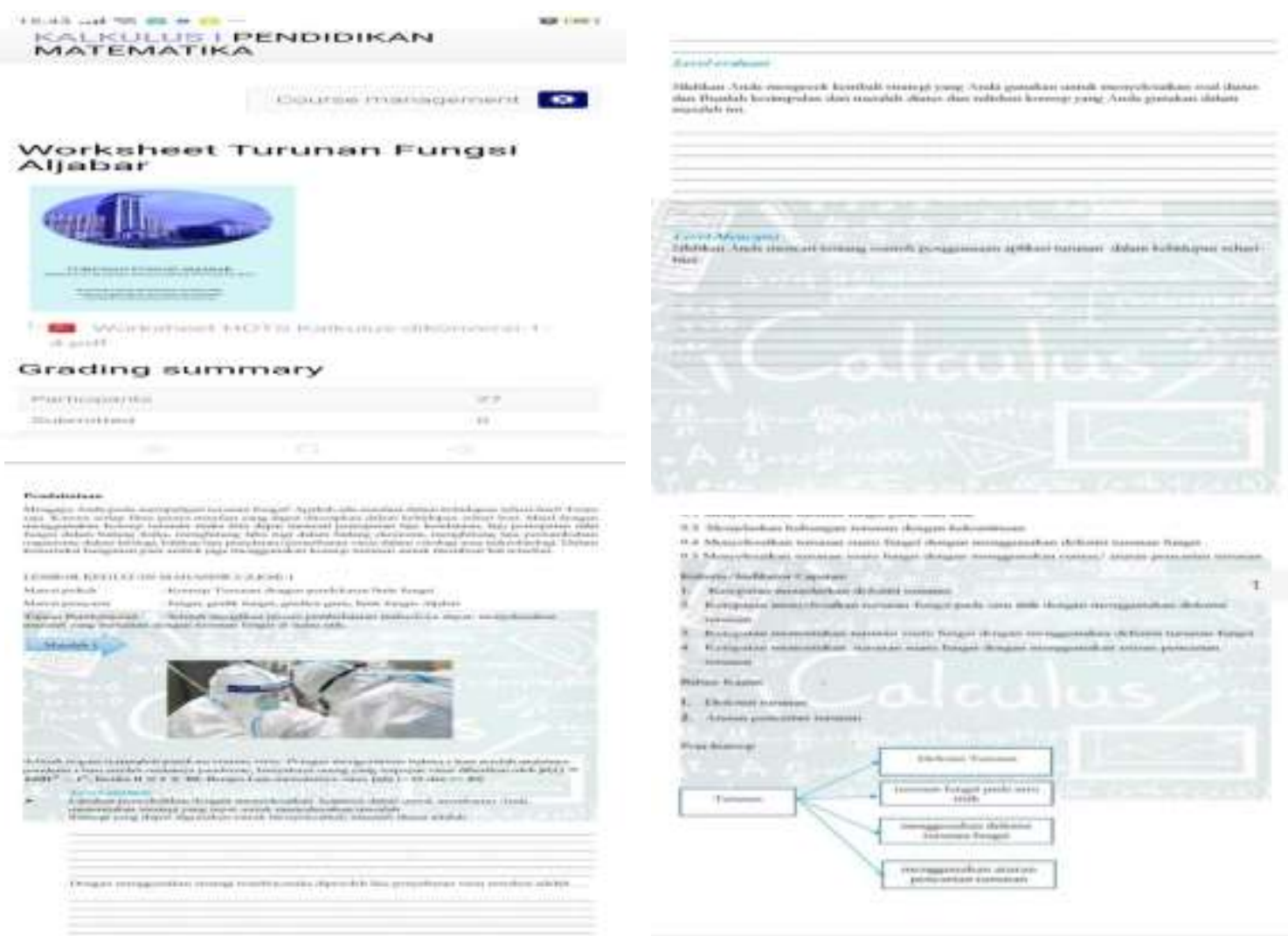

Figure 1. HOTS-Based Worksheet Design Through SPADA 


\section{Develop Stage}

a. Worksheet Validity Test

The results of material expert assessment indicators from the feasibility of the content obtained an average score of 3.56, while the average score on the feasibility of presenting and assessing HOTS was 3.72 and 3.56. The average score of the three aspects of a material assessment is 3.61 is a valid category. Material validation analysis data from experts can see in the following table 5.

Table 5. Material Expert Validation Results

\begin{tabular}{cccc}
\hline No & Assessment indicators & Average & Category \\
\hline 1 & Content Feasibility & 3.71 & Valid \\
2 & Presentation Feasibility & 3.56 & Valid \\
3 & Hots Rating & 3.56 & Valid \\
\hline & Average & 3.61 & Valid \\
\hline
\end{tabular}

The results linguist assessment indicators recapitulating aspects of language feasibility, according to BSNP, include straightforward aspects with an average in the score of 4.00 , communicative aspects with in the score of 4.00, dialogical and interactive aspects with an average score of 4.00 , aspects of conformity with the development of students with an average in the score of 4.00 and conformity with language rules with an average in the score of 4.00 . The average score of the five aspects is 4.00 is a valid category. Language validation analysis data can see in the following table 6 .

Table 6. Valid Results of Linguists

\begin{tabular}{cccc}
\hline No & Rating Indicator & Average & Category \\
\hline 1 & Straightforward & 4.00 & Valid \\
2. & Communicative & 4.00 & Valid \\
3. & Dialogical and interactive & 4.00 & Valid \\
4. & Conformity with language rules & 4.00 & Valid \\
5. & Suitability with student development & 4.00 & Valid \\
\hline
\end{tabular}

Based on the validation results from the three parts, namely material, construction/media, and language in general, it concludes the worksheet is feasible to proceed to the practical stage. After the analysis of the validity, a test carries out. It resulted in the second draft of the HOTSbased worksheet shots. 
b. Practicality Test of the Based Worksheet

The practicality test was carried out to determine whether the parts in the worksheet were practical and easy to use by students and lecturers as users. Limit trials conducted on seven students. The student practicality assessment sheet results showed an average score of 4.15 in the practical category. The lecturer's practicality sheet results show an average score of 3.60 in the practical categories. These results indicate that the LKPD can use properly. LKPD that tested for practicality by producing draft III can use in the learning process. In line with Nurhikmayati and Jatisunda's (2019) opinion, when the student's assessment of the teaching materials developed was good enough, and teaching materials can be used in the learning process in the classroom.

c. Test the effectiveness of the HOTS-Based LKPD

Furthermore, field trials were carried out on 27 students of the Mathematics Education Study Program, FKIP Unismuh Makassar. The effectiveness of the worksheet was analyzed from the results of the pretest and posttest HOTS students and the student responses results. The developed worksheet can be effective if it meets the minimum percentage of completeness criteria and student responses (Prasetyo, 2012). The pretest results showed that the students' average HOTS score was 46.85, including the low category. Furthermore, the results of the HOTS posttest were 74.81 with good categories, while for the results of the questionnaire, the student responses showed a positive response in using the HOTS-based worksheet for function-derived material. This result indicates that the worksheet used is effective.

Furthermore, HOTS-based worksheets through Unismuh's SPADA are feasible to use and can provide an increase in students' HOTS abilities in function-derived materials. From the result of the overall data analysis, the final worksheet product is valid, practical, and effective can be used in the online classroom learning process. In line with the results of Arifin and Retnawati's (2017), the learning designs developed are generally HOTSoriented and have a positive effect in (1) involving students in non-routine problem-solving activities; (2) facilitating students to develop the ability to analyze and evaluate (critical thinking) and creative abilities (creative thinking); and (3) encourage students to build their knowledge. 


\section{Disseminate Stage}

At this stage, distributing HOTS-based worksheets to the Calculus course in all online classes in the Mathematics Education study program at the Muhammadiyah University of Makassar, then students are asked to fill out a questionnaire response to the worksheet distributed. The average result of the student response questionnaire obtained was 3.82 in the good category. That is, students show a positive response to the HOTS-based LKPD. That is in line with the results of Noprinda \& Soleh's research (2019) shows the responses of students to higher-order thinking skill (HOTS)-based worksheets with a percentage of $87 \%$ with the criteria of "very good". So it can be said that the worksheet is ready to be used as teaching material.

The HOTS-based worksheets that are developed provide both theoretical and practical impact. Theoretically, the results of developing this worksheet can be used as a reference for other researchers to develop teaching materials, especially HOTS-based worksheets. Practically, lecturers can use worksheets in learning activities to facilitate students' higher-order thinking skills in the calculus course for the derivative functions. Furthermore, the developed worksheets can be motivating peer lecturers to independently create and develop interest and meaningful teaching materials for students. Students can use that worksheet as a learning resource in class or as a means of independent study at home.

\section{CONCLUSION}

From the results of the research and development were carried out, it produces worksheets based on HOTS through SPADA that have met the valid, practical, and effective aspects and can facilitate students in practicing their higher-order thinking skills. The development of this worksheet product is still limited to one material, and the analysis of the dissemination stage to other classes is only on the distribution of response questionnaires. Therefore, we hoped that there would be a follow-up from both dozen and other researchers to develop teaching materials with different contexts and materials. In addition, further research needs to do to see the effectiveness and effect of using this HOTS-based worksheet.

\section{ACKNOWLEDGMENT}

This research can be carried out well with the help of various parties. In this case, the author would like to thank the Institute for Research 
Development and Community Service (LP3M) of the University of Muhammadiyah Makassar, which has provided the opportunity for the author to make this research one of the winners of the internal grant of the University of Muhammadiyah Makassar.

\section{REFERENCES}

Alam, S. (2019). Higher order thinking skills (HOTS): Kemampuan memecahkan masalah, berpikir kritis dan kreatif dalam pendidikan seni untuk menghadapi revolusi industri 4.0 pada era society 5.0. Prosiding Seminar Nasional Pascasarjana (PROSNAMPAS).

Anggraini, W., Anwar, Y., \& Madang, K. (2016). Pengembangan lembar kerja peserta didik (LKPD) berbasis learning cycle 7E materi sistem sirkulasi pada manusia untuk kelas XI SMA. Jurnal Pembelajaran Biologi: Kajian Biologi Dan Pembelajarannya, 3(1), 49-57. Retrieved from https:// ejournal.unsri.ac.id/index.php/fpb/article/view/4956.

Arifin, Z., \& Retnawati, H. (2017). Pengembangan instrumen pengukur higher order thinking skills matematika siswa SMA kelas X. PYTHAGORAS: Jurnal Pendidikan Matematika, 12(1). https://doi.org/10.21831/pg. v12i1.14058.

Arnellis, Suherman, \& Amalita, N. (2019). Pengembangan learning trajectory kalkulus berbasis high order thinking skills dengan pendekatan realistic mathematics education siswa SMA Kota Padang. Menara Ilmu, 13(6). https:// doi.org/10.33559/mi.v13i6.1399.

Dosinaeng, W. B. N., Leton, S. I., \& Lakapu, M. (2019). Kemampuan mahasiswa dalam menyelesaikan masalah matematis berorientasi HOTS. JNPM (Jurnal Nasional Pendidikan Matematika), 3(2). https://doi.org/10.33603/jnpm.v3i2.2197.

Ikman, Hasnawati, \& Rezky, M. F. (2016). Effect of problem based learning (PBL) models of critical thinking ability students on the early mathematics ability. International Journal of Education and Research, 4(7), 361-374. Retrieved from https://www.ijern.com/journal/2016/July2016/29.pdf.

Karsono. (2017). Pengaruh penggunaan LKS berbasis hots terhadap motivasi dan hasil belajar IPA siswa SMP. Jurnal Pendidikan Matematika Dan Sains, 5(1). https:/ / doi.org/10.21831/jpms.v5i1.13540. 
Khoriyah, M., \& Oktiningrum, W. (2021). Pengembangan soal higher order thinking skills (HOTS) berbasis budaya lokal Blitar untuk mengukur dimensi pengetahuan matematika siswa kelas V sekolah dasar. Bina Gogik: Jurnal Ilmiah Pendidikan Guru Sekolah Dasar, 8(1), 93-100. Retrieved from https://ejournal.stkipbbm.ac.id/index.php/pgsd/ article/view/610.

Kurniawati, W. (2014). Pengembangan perangkat perkuliahan IPA 2 dengan pendekatan problem based learning untuk meningkatkan keterampilan higher order thinking mahasiswa program studi pendidikan guru sekolah dasar. Elementary School: Jurnal Pendidikan Dan Pembelajaran Ke$S D-A n, 1(1)$. Retrieved from https://journal.upy.ac.id/index.php/es/ article/view/788.

Nurhikmayati, I., \& Jatisunda, M. G. (2019). Pengembangan bahan ajar matematika berbasis scientific yang berorientasi pada kemampuan berpikir kritis matematis siswa. Mosharafa: Jurnal Pendidikan Matematika, 8(1), 49-60. https:/ / doi.org/10.31980/mosharafa.v8i1.385.

Nurwahidah, I. (2018). Pengembangan soal penalaran model TIMSS untuk mengukur high order thinking (HOT). THABIEA: JOURNAL OF NATURAL SCIENCE TEACHING, 1(1). https://doi.org/10.21043/ thabiea.v1i1.3874.

Pamungkas, A. S., Kurniasi, E. R., \& Anton. (2020). Pengembangan LKS berbantuan geogebra for smartphone mata kuliah kalkulus diferensial pada materi pertidaksamaan fungsi. INOMATIKA, 2(1), 12-21. https:/ /doi.org/10.35438/inomatika.v2i1.160.

Prasadi, A. H., Wiyanto, W., \& Suharini, E. (2020). The implementation of student worksheet based on stem (science, technology, engineering, mathematics) and local wisdom to improve of critical thinking ability of fourth grade students. Journal of Primary Education, 9(3), 227-237. https:// doi.org/10.15294/jpe.v9i3.37712.

Prasetyo, W. (2012). Pengembangan lembar kegiatan siswa (LKS) dengan pendekatan PMR pada materi lingkaran di kelas VIII SMP N 2 Kepohbaru Bojonegoro. Jurnal MATHEdunesa, 1(1), 1-7.

Prastiti, T. D., Tresnaningsih, S., \& Thaib, D. (2019). Pengembangan lembar kerja mahasiswa berbasis high order thinking skills pada matakuliah matematika di Universitas Terbuka. Jurnal Pendidikan, 20(1), 40-52. https:// doi.org/10.33830/jp.v20i1.231.2019. 
Pratama, N. S., \& Istiyono, E. (2015). Studi pelaksanaan pembelajaran fisika berbasis higher order thinking (HOTS) pada kelas $X$ di SMA Negeri Kota Yogyakarta. Seminar Nasional Fisika Dan Pendidikan Fisika Ke-4 2015.

Rahmatillah, R., Halim, A., \& Hasan, M. (2017). Pengembangan lembar kerja peserta didik berbasis keterampilan proses sains terhadap aktivitas pada materi koloid. Jurnal IPA \& Pembelajaran IPA, 1(2), 121-130. https:// doi.org/10.24815/jipi.v1i2.9686.

Saregar, A., Latifah, S., \& Sari, M. (2016). Efektivitas model pembelajaran cups: dampak terhadap kemampuan berpikir tingkat tinggi peserta didik Madrasah Aliyah Mathla'Ul Anwar Gisting Lampung. Jurnal Ilmiah Pendidikan Fisika Al-Biruni, 5(2), 233-244. https://doi.org/10.24042/ jpifalbiruni.v5i2.123.

Widana, I. W. (2018). Higher order thinking skills assessment towards critical thinking on mathematics lesson. International Journal of Social Sciences and Humanities (IJSSH). https://doi.org/10.29332/ijssh.v2n1.74.

Widyawati, A., \& Sujatmika, S. (2020). Electronic student worksheet based on ethnoscience increasing hots: literature review. International Conference on Technology, Education and Science, 27-31.

Wulandari, T. N., \& Susanti. (2019). Pengembangan lembar kegiatan peserta didik (LKPD) berbasis higher order thinking skills (HOTS) pada mata pelajaran akuntansi perbankan syariah kelas XI Semester I di SMK. Jurnal Pendidikan Akuntansi, 7(3), 347-252. Retrieved from https:// ejournal.unesa.ac.id/index.php/jpak/article/view/30693.

Yee, M. H., Widad, O., Jailani, Y., Tee, K. T., Razali, H., \& Mohaffyza, M. M. (2011). The level of marzano higher-order thinking skills among technical education students. International Journal of Social Science and Humanity, 1(2), 121-125. Retrieved from http://ijssh.org/papers/20H009.pdf. 